\title{
Détente, Entente, or Linkage? The Helsinki \\ Conference on Security and Cooperation in Europe in U.S. Relations with the Soviet Union
}

\section{In trod u c t i o n}

The idea of a conference on European security problems that might provide an alternative to the post-war bloc-to-bloc divide of the continent dates back to the fifties. For fifteen years, the Soviet Union and its allies advanced proposals on this issue, always meeting with Western indifference, skepticism, or overt opposition. The Soviet Union aimed, sometimes overtly, at setting conditions likely to hamper the Western integration - North Atlantic Treaty Organization (NATO), European Communities, Multilateral Force (MLF) project, and nuclear potential sharing. The Kremlin also looked for a solution of the German question that might guarantee either neutralization of all of Germany or recognition of the German Democratic Republic. The Western governments thought that the Kremlin wanted a multilateral conference to fix a European settlement in which Communist bloc's territorial and political realities were confirmed and recognized and to promote such a relaxation of tensions as to make an American presence in Europe superfluous. Consequently, the Western powers always rejected Soviet appeals and devoted to the strengthening of the Atlantic bloc. Furthermore, the government of West Germany stuck to its "Hallstein doctrine," according to which the only solution to the German question was reunification through free elections and full sovereignty of the new German state. ${ }^{1}$

A significant relaxation of tensions between East and West occurred since the mid-sixties. Between 1963 and 1968 an increasing dialogue between the superpowers started to develop. Its genesis was in the Soviet achievement, in 1964-65, of the second-strike capability on nuclear weapons, which meant the possibility of mutual assured destruction (MAD) in case of war. The imminent strategic parity between the superpowers created the balance of terror-deterrence-and engendered the political will to pursue limitation to the nuclear armaments race and to define rules to manage the nuclear arsenal. In October 1966, during

The literature on the dialogue between the blocs throughout the decades is overwhelming. See, for example, Wilfred Loth, Overcoming the Cold War: A History of Detente, 1950-1991 (Basingstoke, England, 2002). 
a speech in New York, U.S. President Lyndon B. Johnson invited the Soviet Union to resume the détente process by agreeing on military troop reductions on both sides in order to create an increasing reconciliation in Europe. ${ }^{2}$ Two years later, on July 1, 1968, the Nonproliferation Treaty was signed and created the basis for managing the world nuclear arsenal.

The process of détente between the two superpowers gave Western European governments more room for maneuver in their Eastern policy. Many initiatives took place in the late 1960s. French Gaullist policy and West Germany's Neue Ostpolitik are widely known. ${ }^{3}$ In July 1966, the British tabled at NATO a proposal for a code of good behavior in East-West relations. ${ }^{4}$ The Italian government signed relevant economic agreements. The Belgian government pursued an intensive Eastern policy, mostly with the Czechs and Poles, in order to promote economic and political relations. ${ }^{5}$ A sort of European détente developed in parallel with, and thanks to, the bipolar one. Finally, NATO collectively endorsed détente as a major goal: in December 1967, the Harmel Report on the future tasks of the Atlantic alliance coupled détente with strong allied solidarity. ${ }^{6}$ When new U.S. President Richard Nixon in his inaugural speech called for an "era of negotiations," all circumstances seemed favorable for the European Security Conference.

In fact, the Warsaw Pact Political Committee relaunched the proposal on March 17, 1969. The NATO member states examined it on the occasion of the Washington meeting for the twentieth anniversary of the Atlantic alliance. The Western Europeans asked for a positive-even though cautious - reply to the Budapest appeal, while the American position was lukewarm. ${ }^{7}$ The Atlantic Council eventually accepted the idea at the December 5, 1969, meeting in Brussels and set some preliminary conditions to the conference: a successful conclusion of the Ostpolitik treaties, a satisfying quadripartite agreement on

\footnotetext{
2 National Records and Archives Administration, Public Papers of the Presidents of the United

States: Lyndon B. Johnson, 1966 (Washington, DC, 1967), 1125-30.

3

See for example: T. F. Banchoff, The German Problem Transformed: Institutions, Politics and Foreign

Policy, 1945-1995 (Ann Arbor, MI, 1999); W. Brandt, Memorie (Milano, 1991); See M. Vaïsse, La Grandeur. Politique étrangère du Général de Gaulle, 1958-1969, (Paris, 1998); M.P. Rey, La tentation du rapprochement: France et URSS à l'heure de la détente (1964-1974), (Paris, 1991).

4

Proposition britannique d'un "code de bonne conduite pour les relations Est-Ouest"

( July 1966-67), série: Europe 1944-70, sous-série: Grande Bretagne, Dossier no. 223, Archives

du Ministère des affaires étrangères, Paris, France (hereafter AMAE).

5

Dossier général, série: Europe 1944-70, sous-série: Belgique, Dossier no. 157, AMAE;

see also V. Dujardin, Pierre Harmel: Biographie (Bruxelles, 2005). See B. Bagnato, Prove di Ostpolitik. Politica ed economia nella strategia italiana verso l'Unione Sovietica 1958-1963, (Firenze, 2003).
}

6 Final Harmel Report, "East-West Relations Détente and a European Settlement," found

at http://www.nato.int/archives/harmel/harme101.htm.

Memorandum for the President from the Secretary of State, "United States and Allied Approaches to the Current Issues of European Security," October 31, 1969, NSC Country Files, Box 683, Nixon Persidential Materials, College Park, Maryland (hereafter NPM); see also G. Finocchiaro, La Conferenza per la Sicurezza Europea. Il dibattito internazionale fino al 1972 (Padova, 1977). 
Berlin, and the start of negotiations on force reductions in Europe (MBFR) ${ }^{8}$ Once these preconditions fulfilled, the West gave its formal assent to open the Multilateral Preparatory Talks (MPT) for preparing the conference.

From November 22, 1972, to June 8, 1973, the heads of diplomatic delegations from thirty-five countries - the United States, Canada, all European states except Andorra and Albania-informally gathered in Helsinki and debated site, phases, agenda, and negotiation procedures of the conference. The first phase of the conference occurred in Helsinki, on July 3-7, 1973. The foreign ministers of the participating states adopted the Final Recommendations of the Helsinki MPT and set the opening date and site of the second phase - the negotiations. On September 18, 1973, more than six hundred delegates and experts met in the brand new hall of the Palais des Nations in Geneva and opened the substantive phase of the Commission on Security and Cooperation in Europe (CSCE). They were to discuss four main issues - the so-called baskets: principles governing relations among the participant states and confidence-building measures; cooperation in the fields of economics, science, and technology and environment; cooperation on human contacts and other fields; follow-up to the conference.

Although the CSCE was generally considered the most significant diplomatic gathering since WW II, the expectations of the participants varied from skepticism by the United States to enthusiasm by Romania. In November 1972, few delegates could foresee what the negotiations would bring about. According to memoirs of several participants, the course of the conference developed together with the negotiation itself and the expectations of the participants changed frequently throughout the long haul to the Final Act. ${ }^{9}$ During the first four months, the delegations were devoted to general discussions on the various proposals in a climate of dialogue and cooperation. The drafting of texts started in February 1974 and engendered the real hard bargaining. The rule of consensus applied to such a rich and complex agenda contributed in making the CSCE the long negotiation we know. The necessity of reaching the unanimity of facade engendered ad hoc alliances on different topics, continuous games of bargaining and pressure - made up alternately of connivance and arm-twisting - where the determinant elements of success were both the ability to resist and the skill in tabling package deals and overcoming deadlocked situations. At the same time, the intentional search for solutions that might satisfy all participants led to 
reconciling even the irreconcilable positions, making the Final Act an ambiguous document in which every government could find, and consequently underscore, the more suitable and palatable provisions. The third phase of the conference was held in Helsinki, from July 30 to August 1, 1975. The heads of state and government of the participating countries met for a solemn ceremony to sign the Final Act before the world press. In their statements, it is possible to notice all the potentialities and limits of the document, both in its nature and contents.

The CSCE seemed to be, and has long been considered as, the seal on détente, or a diplomatic parade celebrating previous substantial agreements between East and West. Consequently, it has been long overlooked in the literature on international relations. A few works have been published on national approaches to the Helsinki CSCE, providing an insight in governments' policy on the CSCE: rationales, goals, preparation, tactics, and results. ${ }^{10}$ In recent years, many scholars have devoted to the analysis of the CSCE, its significance, and its development, from the political, historical, or juridical point of view. ${ }^{11}$ It is becoming evident that presumably each country participating in the CSCE assigned the conference a specific role in its foreign policy. In the case of the United States, the Helsinki CSCE appears to be marginal and mostly considered in relation to two general goals: the strengthening of NATO solidarity and cohesion, on the one hand, and improvement of the relationship with the Soviet Union, on the other. Although attention to the Atlantic solidarity was present throughout the preparation and the negotiations, archival sources show that the White House's main criterion in tailoring the CSCE policy was the relationship with the Kremlin. The CSCE may be seen as an instrument of U.S. détente, as well as Strategic Arms Limitation Treaties (SALT) or trade and cooperation agreements. It may even be seen, and has been, as an occasion of entente between the superpowers. Or, finally, and it is the opinion of the author in this article, it may be considered as a case of application of the linkage theory that characterized the Nixon-Kissinger administration. ${ }^{12}$

See, for example, Ferraris, Testimonianze di un negoziato; Maresca, To Helsinki.; R.

Spencer, ed., Canada and the Conference on Security and Cooperation in Europe (Toronto, 1984); A.

Carrascosa Coso, Santa Sede Y la conferencia sobre la seguridad y la cooperation in Europa: Helsinki, Ginebra, Helsinki (Vatican City 1991).

${ }^{11}$ See J. Andréani, Le Piège, Helsinki et la chute du communisme, (Paris 2005); C. Meneguzzi Rostagni ed., The Helsinki Process. A Historical Reappraisal, (Padova, 2005); O. Bange and G. Niedhart, eds., Helsinki 1975 and the Transformation of Europe, (Oxford 2008); A. Menger, V. Mastny and C. Nuenlist, eds., Origins of the European Security System: The Helsinki Process Revisited, 1965-75, (London, 2008); A. Romano, From Détente in Europe to European Détente, (Bruxelles, 2009).

This article is mostly based upon sources from the following archives: National Records and Archives Administration (NARA) and the Nixon Presidential Materials Project-College Park, Maryland, Gerald Ford Presidential Library - Ann Arbor, MI, Historical Archives of the European Union-Florence, Italy, EU Council Archive-Brussels, Belgium, National Archives - London, UK, Archives du Ministère des Affaires étrangères-Paris, France. 


\section{the nixon-kissingerconceptionof bi polar r lations: DÉTENTE}

U.S. President Nixon took the inheritance of his predecessor on dialogue with the Soviet Union and détente and improved it by setting principles and methods. Nixon's point of departure was a reappraisal of the American worldwide involvement and responsibilities: he saw in the new international situation-Vietnam disaster, crisis of the internal consent, financial problems, strategic parity with the USSR - the end of the policy of containment, which had been guiding the American action since 1947. A global and multidimensional engagement was no more bearable. The United States had begun to suffer financial consequences from the engagement with the Communist threat everywhere in the world, while new economic and political powers were emerging on the international arena: Japan, Western Europe and its European Community, China. It was necessary to regain more room to maneuver and to protect national interests, without shifting to a blind and inconceivable isolationism. Although various political poles were emerging, the structure of the international society remained military and strategically bipolar. Consequently, Nixon thought that U.S. foreign policy should follow two fundamental paths: (1) recognition of allies' bigger political and economic role coupled with a redistribution of responsibilities and burden sharing, on the one hand and (2) a concrete dialogue between the superpowers aimed at maintaining reciprocal deterrence and international stability, on the other. ${ }^{13}$

Nixon was well aware that the Soviet long-term goal remained the annihilation of capitalism and the realization of a worldwide Communist society. However, he believed that the Soviets might find it interesting and convenient to shift from confrontation with the United States and its allies to competition and, in some cases, to mutually advantageous cooperation. As a corollary, Nixon and his National Security Adviser Henry Kissinger resumed one of the most classical means of diplomacy: the technique of the carrot and the stick. The Nixon administration was ready to recognize the Soviet Union as a fundamental pillar of the international order and would therefore give it incentives for the maintenance of this role. At the same time, the American government would envisage some penalties in order to discourage Moscow from unfair play and from taking advantage of crises at the expenses of the United States..$^{14}$ Détente for the Nixon administration was not and end in itself. It was the strategy and the means, rather than the objective and the goal. ${ }^{15}$ The goal was to secure stability

\footnotetext{
13

"President's US Foreign Policy for the 1970's. Report to the Congress," March 14,

1974, National Security Adviser-Staff Assistant Peter Rodman: Files, (1970) 1974-77, Box 1,

Folder: Foreign Policy - President's Annual Review, Gerald Ford Presidential Library, Ann

Arbor, Michigan (hereafter FPL).

NSC Meeting, "Strategic Issues-East/West Relations 2/19/69," NSC Institutional "H" Files, Box H-020, NPM. 
of the bipolar order and, fundamentally, to gain the United States new freedom of action at lower cost. If détente was the strategy, linkage was the tactic. The interrelation of international events, on a global chessboard and on all fieldslinkage - became the diplomatic tool for applying the incentives and the penalties that were at the center of the strategy of Nixon and Kissinger. It is in this framework that the U.S. approach to the CSCE has to be considered. According to the linkage theory, the conference could be a good "carrot" to induce the Soviets to be more cooperative on other issues. A pan-European security conference legitimizing the status quo in Europe was compatible with the fundamental premises of Nixon's foreign policy: enhance Western solidarity, all the more so given the West German government's Neue Ostpolitik, and involving the USSR in the management of the bipolar order. ${ }^{16}$

\section{the u.s.policyon cse}

The Road to Helsinki: 1969-72

During the first period of the Nixon presidency, two U.S. policies on CSCE coexisted: one developed by the Department of State, the other led by the National Security Council (NSC), namely by Henry Kissinger.

From December 1969 to the spring 1972, the Department of State, namely the Office of European Affairs, enjoyed a great deal room in handling the CSCE issues and related consultations with NATO allies. From the spring 1970, the Department of State - though sharing the White House's perplexities that the conference might result in a mere "atmospheric détente"-was interested in the possibility of favoring more room to maneuver the Eastern European countries in foreign policy and promoting a gradual process of liberalization of their regimes. It also thought about using the theme of human rights and freedoms to challenge the Soviet hegemony in the area. The Department of State therefore introduced the issue of freer movement of peoples, ideas, and information in NATO consultations, and tabled proposals on practical measures aimed at realizing these goals. ${ }^{17}$ It is worthy to notice here that the American proposals had such a maximalist approach as to meet with the perplexity of the European allies, which did not want the CSCE to become a confrontational meeting. ${ }^{18}$

\footnotetext{
16 On the United States and the Ostpolitik, see, for example, R. M. Nixon, The Memoirs of Richard Nixon (New York, 1978); H. A. Kissinger, White House Years, (Boston, 1979); D. C.

Geyer and B. Schaefer, eds., American Détente and German Ostpolitik, 1969-1972”, in Bulletin Supplement n. 1, German Historical Institute (Washington, 2004); G. Bernanrdini, "Le relazioni europee hanno voltato l'angolo.” L'Amministrazione Nixon e il governo Brandt: Europa, Occidente, rapporti con l'Est, 1969-1971 (Firenze, 2005). (hereafter RG) 59, NARA. 
The White House, on the contrary, had neither interests in nor enthusiasm for the CSCE and was mainly concerned with the necessity of limiting possible damages of such an adventure. First, the Conference was not to prejudice NATO or to question the presence of the United States on the European Continent (i.e., American troops, U.S rights on West Berlin). The Nixon administration, as well as Western European governments, feared that the conference might induce such a sense of relaxation and unjustified euphoria in public opinions as to make it increasingly difficult to pass a military budget. The U.S. government was already facing congressional requests of substantial and unilateral reduction of American troops in Europe (i.e., Senator Mansfield's resolution). Whatever the achievements of the East-West dialogue, there were no doubts that Western security still needed a strong and effective NATO.

Second, and accordingly, negotiations on fundamental security issues were to be kept out of a conference involving some thirty countries, including the neutral and nonaligned states. These issues were to be discussed in a separate and appropriate forum - the Mutual and Balanced Force Reduction (MBFR) talksand develop in advance of, or in parallel with, the CSCE. The MBFR had been proposed in June 1968 by the Atlantic Council in Reykjavik for maintaining the existing level of security by minor costs and without destabilizing the continent. The MBFR negotiations were fundamental for the Nixon administration to handle the internal pressures for unilateral reduction of troops in Europe. Consequently, the White House made the MBFR an essential prerequisite to the CSCE. ${ }^{19}$ The priorities of Nixon and Kissinger were never put into question: the CSCE was, first and foremost, a bargaining chip in negotiations with the Soviet Union to gain concrete solutions of fundamental questions such as the Ostpolitik treaties, the agreement on Quadripartite Rights on Berlin, the SALT treaty, and the start of MBFR negotiations. ${ }^{20}$ The U.S. government therefore withheld its assent and engaged in slowing the convening of the conference until satisfactory results had been secured on these issues. ${ }^{21}$

The Nixon administration had little interest in the CSCE issues. With regard to the principles governing relations among the participant states, the major American interests were to avoid that CSCE provisions affecting Quadripartite

Box "Presidential Guidance on Mutual and Balanced Force Reductions and a European Conference," December 2, 1971, NSC Institutional "H” Files, Box H-229, NSDM 142 NPM. NSSM-83, NPM. 
Rights and Responsibilities (QRR) on Berlin, on the one hand, and to support West Germany's demand for a clause on peaceful change of frontiers that was to preserve future chances of reunification, on the other. As the Western European governments fully shared these goals, the United States left the leadership to its allies, which were more involved in the CSCE experience. The same can be said about cooperation on economics and other fields, which the Nixon administration was negotiating bilaterally with the Soviet Union. In a coalition of fifteen countries, the U.S. government decided not to take a leadership position and not to impose positions on issues that were considered of minor importance. It can be said that on the road to the CSCE the U.S. main goal and concern was the preservation of the Atlantic solidarity rather than the negotiation of East-West agreements. Consequently, the Americans stood flexible on the CSCE and contributed to Western preparation within NATO mainly by not opposing European allies. ${ }^{22}$ It is worthy to notice, however, that this attitude also allowed Washington to keep the Western European governments from giving premature assent to convene the conference without due and full satisfaction of the Western prerequisites.

The White House chose a low profile attitude in order to strike a balance between supporting the Western positions and shaping its dialogue with the Soviets. ${ }^{23}$ Given these considerations, it is difficult to see the CSCE as a proper element of the U.S. détente with the Soviet Union. Neither Nixon nor Kissinger expected any practical results from the CSCE. They thought it would provide at least "atmospheric détente" and considered it to be important for the Western European allies that, in their view, "look[ed] upon European Security negotiations as their equivalent to SALT." ${ }^{24}$ The White House continued to be skeptical on the CSCE aims: neither the confirmation of the status quo nor the development of a vague cooperation seemed to deserve the efforts requested by the meeting. Détente with the Soviet Union should develop on more concrete issues and negotiations and, above all, bilaterally. What the CSCE provided the Nixon administration with was a good carrot to induce Soviet cooperative behavior on major issues. Not only did the Soviet Union take the CSCE in great consideration, but Brezhnev himself had also invested his own efforts and reputation in the event. Once the United States obtained satisfaction on its requests, the CSCE was deprived of its bargaining value and became the promised concession to the Soviets, who had major interests in pursuing it.

\footnotetext{
22

Memorandum for the President from Rogers, "United States and Allied Approaches

to the Current Issues of European Security," October 31, 1969, NSC Country Files, Box 683, FolderFolder 1, NPM. 


\section{2-74: Superpowers' Entente?}

In 1972, the Department of State's ideas on CSCE, which had never enjoyed much echo at the White House, became incompatible with Nixon's approach to U.S.-Soviet relations. In a year of presidential elections, the immediate and most important challenge to Nixon was to honorably disentangle the country from the Vietnam War. To this aim, the development of good relations with China and an improvement in the relationship with the USSR were to contribute to easing the way out. ${ }^{25}$ In February 1972, Nixon astonished the world by his official trip to Beijing, which had been secretly prepared by Kissinger the previous year. In May, for the first time, an American president visited the Soviet Union.

At the Moscow summit, the dialogue between the superpowers brought the highest results: the SALT I treaty, the Soviet assent to convene the MBFR talks, trade and cooperation agreements in various fields, and the Declaration on Basic Principles of U.S.-Soviet Relations. On that occasion, Nixon could no longer procrastinate on giving U.S. consent, in principle, to the CSCE.

The Basic Principles came as a surprise to Western European allies. They had not been informed about it, despite the fact that in his first diplomatic trip to Western European capitals in February 1969, Nixon had provided assurance that negotiations with the Soviets would be based on full consultation with NATO allies. In actuality, the Nixon government gave this document minimal publicity because it did not consider it of fundamental importance. All statements by Nixon and Kissinger on this issue clearly suggested that the administration regarded the Basic Principles as a road map for future relations with the USSR, not as a cookbook with set recipes. ${ }^{26}$ Nonetheless, it caused some uneasiness and concern in Western European governments that noticed two clear signs of a possible bipolar entente. First, the United States had endorsed the concept of peaceful coexistence, a long-standing Soviet term, without even putting its own interpretation on record at the summit meeting. Neither the French-Soviet declaration nor the German Ostpolitik treaties had gone so far. Second, and more worrying, there was a significant omission of reference to human rights issues in American statements on the Soviet regime. ${ }^{27}$ It is meaningful that Nixon himself, speaking to the Soviet population when in Moscow, affirmed: "The only sound basis for a peaceful and progressive international order is sovereign equality and mutual respect. We believe in the right of each nation to chart its own course, to choose its own system, to go its own way, without interference from other nations." ${ }^{28}$ Furthermore, the joint U.S.-Soviet

On the Nixon administration and the Vietnam War, see, for example, K. L. Nelson,

The Making of Détente: Soviet-American Relations in the Shadow of Vietnam (Baltimore, J, 1995); J. Kimball, Nixon's Vietnam War (Lawrence, KS, 1998). of Principles," June 19, 1973, NSC Country Files, Box 687, Folder 2 (1 of 3), NPM. 
declaration confirmed mutual respect of political systems and called merely for improvement in relations and contacts. Finally, the description of the U.S. goals at the CSCE did not mention human rights, and the slight reference to the widening of human contacts did not fill the gap. This attitude was far from the position that the Atlantic Alliance, and the West European countries in particular, was preparing for the conference. The contrast clearly showed up in the subsequent months.

After the Nixon-Brezhnev summit, the White House took over the leadership of the U.S. policy on the CSCE. It gave the policy a direction that seemed all the more to aim at depriving the conference of any chances to reach concrete results. In a talk with British Cabinet Secretary Burke Trend, Nixon himself explicitly affirmed that the U.S. government had never wanted the CSCE and that it had been the European countries, including the United Kingdom, that had insisted on Western acceptance. ${ }^{29}$ In subsequent bilateral contacts, the Americans informed the British that they were not going to take a leadership role on any issues of the conference. ${ }^{30}$

The West had set two fundamental goals at the CSCE: the invalidation of the Brezhnev doctrine and the promotion of freer movement of people, ideas, and information. In his report on U.S. foreign policy in February 1972, President Nixon still defined the Soviet threat or use of force in Eastern Europe as being incompatible with détente. ${ }^{31}$ Nonetheless, in summer 1972, the NSC questioned whether "in light of our relations with the USSR, we want to appear as the leading advocate and champion of the anti-Brezhnev doctrine thrust, or begin to retreat from any untenable positions." 32 Also on the freer movement issue, the United States toned down the requests. On the road to MPT, Kissinger's main aide for European affairs, Helmut Sonnenfeldt, admitted "through bureaucratic inertia we have not really re-examined this since 1969, when it might have been tactically justified as a measure to badger the Soviets." ${ }^{33}$ Sonnenfeldt openly informed the British that the U.S. government regarded the CSCE as an element of the overall relationship with the Soviet Union. Owing to the new relationship with Moscow, the White House was unwilling to introduce an element of attrition such as the freer movement topic. This attitude denoted

Minute from Sir T. Brimelow to Mr Wiggin, "Talk with Dr. Kissinger in Washington,

10 August 1972," FCO, August 14, 1972-Secret, Document no. 12 in Documents on British

Policy Overseas, Series III, Vol. II, The Conference on Security and Cooperation in Europe, 1972-75, ed. G. Bennett and K. A. Hamilton (London, 1997).

Minute from Mr. Tickell to the Private Secretary, FCO, September 20, 1972-Secret, note 12 in Document no. 13 in Documents on British Policy Overseas. 
a lack of political wisdom on the part of the American administration, which failed to recognize the potentiality of the Third Basket. Furthermore, the U.S. approach did not take into due consideration the views of the European allies, which thought it very important to extend the contacts across the Iron Curtain. The Western European governments became more and more exasperated by the American drawback. It seemed to them that the president of the United States had yielded to the Soviet firmness to police the traffic between East and West. ${ }^{34}$ When MPT started in Helsinki, the U.S. delegation adopted a low profile, if not a passive attitude..$^{35}$ Although both the U.S. delegation and the Department of State wished to cooperate actively within the Western front, they supposed that the White House could send unfavorable instructions. During the MPT the skilful leadership of George Vest, the head of the American delegation, assured close compliance with the strategy and decisions of the alliance, despite of - or thanks to-missing instructions from Washington. Although at the ministerial meeting of the CSCE, in July 1973, the U.S. Secretary of State William Rogers underscored the importance of the Third Basket for the American government, the European allies doubted that Kissinger would agree on the same line and stand firm on humanitarian issues. They were aware that the White House did not share the point of view of the Department of State. One month later, in August, Rogers resigned, and Kissinger was appointed secretary of state. The existing dichotomy between the position of the Department of State and that of the White House was eventually overcome. The first consequence was the removal of Vest from the CSCE delegation and the appointment of Davis Eugene Boster, who lacked any experience in international negotiations. A few months later, another turnover brought Albert Sherer, former ambassador to Prague, at the head of the U.S. delegation to Geneva. Lacking in instructions from Washington and weakened by two changes of leadership, the U.S. delegation to the CSCE limited itself to discretely supporting the efforts of the European allies, according to NATO guidelines. ${ }^{36}$ The Nixon administration had clearly chosen not to make the CSCE a reason of attrition with Moscow.

The views of the U.S. presidency were not unknown to the Western European governments. In particular, they expected a dramatic change of U.S. attitude at the CSCE as soon as Kissinger, at the time busy with negotiations on Vietnam, could turn his attention to the pan-European conference. ${ }^{37}$ This

Tel. no. 12287 from AmEmbassy Bonn, "CSCE: FRG views on US position at MPT," December 20, 1972, NSC Country Files, Box 687, Folder 1 (2 of 2), NPM; Submission from Mr Tickell on CSCE: Multilateral Preparatory Talks-Confidential-FCO, December 21, 1972, Document no. 19, in Documents on British Policy Overseas. 
suspicion was soon to be confirmed. At the beginning of March 1973, in a talk with Luxembourg Foreign Minister Gustav Thorn, Kissinger overtly accused the European allies of being constantly "unhelpful" on CSCE and MBFR, and affirmed that they should let the Soviets have what they wanted: "a short snappy conference with little substance." He added that the question of freer movement might have a tactical value but was not likely to bring any practical results. ${ }^{38}$ In a meeting with NATO permanent representatives at San Clemente, in June, Kissinger clearly stated that MBFR talks were much more important than CSCE and that it was not helpful to challenge the Soviets by asking for human contacts provisions or whatever else could be unacceptable to Moscow. ${ }^{39}$ Being involved in bilateral negotiations with the Soviet Union-SALT II, Middle East, Vietnam, MBFR - the Nixon administration did not want the CSCE, a regional conference lacking any intrinsic value, to undermine the entente between the superpowers on major international problems.

From the Helsinki MPT to Nixon's resignation, not only did the United States remain passive on human contacts, but also pressed upon allies to speed up the negotiations and let a CSCE conclusive summit occur as soon as possible. ${ }^{40}$ If the head of the Office of European Affairs had diplomatically informed the British that the U.S. government was inclined to favor a top-level CSCE conclusive summit, Kissinger told the Dutch foreign minister that the summit had to be accepted, because "Europe [could] not say no to the Soviets on this point. ${ }^{, 41}$ Kissinger's numerous statements on the indifference of White House to the CSCE and on the pointlessness of the human contacts question nourished the suspicion of an entente between the superpowers over the Europeans' heads. It is significant that in March 1974 the British, who had long tried to build bridges between the United States and the Western European countries, bitterly suggested that the Europeans "should not rely upon the Americans to fight too hard against a summit however meagre the results of the second stage."42

Letter from Mr. J.A.N. Graham (Washington) to Mr. Bullard, Washington, March 12,

1973-Personal and Confidential, Document no. 25, in Documents on British Policy Overseas.

J. Goodby, Draft Paper, "The Origins of the Human Rights Provisions in the Helsinki Final Act," presented at CIMA International Conference "The Road to Helsinki," Florence, September 29-30, 2003.

Tel. no. 218, Miss Warburton (UKMIS Geneva) to Mr Callaghan, "General Situation," Geneva, March 20, 1974-Priority, Confidential, Document no. 69, in Documents on British Policy Overseas; Memorandum of Conversation (Brezhnev, Podgorny, Kosygin, Bobrynin, Korniyenko, Nixon, Kissinger, Stoessel, Haig, Sonnenfeldt, Hartman, Hyland), "Test Ban; Mediterranean Nuclear Ban; CSCE,” June 29, 1974 NSC HAK Office Files, Box 77, Folder 3, NPM; Tel. no. 692, Mr Hildyard (UKMIS Geneva) to Mr Callaghan, "US Policy towards CSCE," Geneva, July 24, 1974-Priority, Confidential, Document no. 92, in Documents on British Policy Overseas; Maresca, To Helsinki, chap. 10.

Tél. no. 5747 de AmbaFRA aux Etata-Unis, "Visite à Washington du Ministre des Pays-Bas: CSCE,” Washington, September 21, 1973, série: Europe 1971-juin 1976, sous-série: Organismes Internationaux et Grandes Questions Internationales, dossier 2926, AMAE. 
At the NATO ministerial meeting in Ottawa, in June 1974, Kissinger denied either that the White House wanted to hasten works in Geneva or that it favored a top-level final summit. Two weeks later, the joint communiqué issued at the end of Nixon's second visit to Moscow stated that the completion of the CSCE would be an outstanding event in the interest of establishing a lasting peace and that the two superpowers favored a final phase to be convened as soon as possible "at the highest level, which would correspond to the historic significance of the Conference for the future of Europe and lend greater authority to the importance of the Conference's decisions." ${ }^{\text {,43 }}$ Although Kissinger tried to reassure the European allies that the U.S. government had not changed its views or agreed bilaterally with the Soviets, his subsequent actions denied his words. He actually urged the Europeans to conclude the negotiations soon. He described the Geneva talks as "over-bureaucratic" and said that delegations were each engaged in presenting shopping lists, mostly on the Third Basket. The Western delegations, he added, should not waste time chatting, but rather should present a list of their essential, and reasonable, requests, the acceptance of which would eventually lead to a top-level final summit. Although he declared himself in favor of the promotion of Western values, he reminded the allies that the Soviet Union had been there for fifty years and would certainly not change because of Western newspapers being sold in Moscow..$^{44}$ In NATO meetings in July, the American delegation further explained the U.S. views: the West should reduce its request to some six or eight fundamental measures and somehow convey them to the Soviet Union. This would let Moscow have a better sense of the concessions required of them to achieve the third phase of the conference. Then the West should leave the bargaining to delegations in Geneva. ${ }^{45}$ The United States clearly aimed at closing the conference by summer 1974 .

If one considers bilateral conversations, it is evident that in 1974 the two superpowers shared substantial common views on the conference. They both were annoyed by the slowness of the Geneva negotiations and the irreducible attitude of Western European delegations and of minor neutral countries, all the more so with regard to Third Basket issues that they considered unrealistic. ${ }^{46}$ In their bilateral talks with Soviet representatives, the Americans entirely charged their European allies with the responsibility for the stalemate in the negotiations and repeated that the United States had no interests in

\footnotetext{
43 Public Papers of the Presidents of the United States. Richard Nixon, 1974 (Washington, DC, 1975), 571-72.

Tel. no. 350 from Sir E. Peck (UKDEL NATO) to Mr. Callaghan, "Kissinger Briefing:

CSCE," Brussels, 4 July 1974-Confidential, Document no. 89, in Documents on British Policy Overseas.

Tel. No. 692 from Mr Hildyard (UKMIS Geneva) to Mr. Callaghan, “US Policy towards CSCE”, Geneva, 24 July 1974, Document no. 92 in Documents on British Policy Overseas.

46 
changing the Soviet system. The U.S. government considered it necessary to agree on some humanitarian measures likely to facilitate contacts among the European citizens, but it had no problems in accepting the principle of respect of national laws and customs that the Soviets vigorously requested. ${ }^{47}$ Knowing that the European allies would never accept such a provision in the preamble to the Third Basket, the Americans tried to work out a compromise: the clause could be included in the principle on sovereignty, and the preamble to the Third Basket would refer to the list of principles guiding relations among the participating states. It is noteworthy that Kissinger and Soviet Foreign Minister Andrei Gromyko agreed to make the Finnish delegation table the proposal in order to avoid as the appearance of a superpowers' entente over the heads of the Europeans. ${ }^{48}$

The presidential turnover in the United States, due to the Watergate scandal, did not seem to change the U.S. policy on the CSCE. The joint U.S.-Soviet communiqué issued at the end of the Ford-Brezhnev summit in Vladivostok, in November 1974, called for the conclusion of the conference as soon as possible and at the highest level.

If we look at the U.S. attitude towards the CSCE from the point of view of the negotiations, and above all from the point of view of the Western European governments, it is hard not to share the impression of an existing entente between the superpowers over the Europeans' heads and at the expenses of human rights and freedoms issues. However, in this interpretation, it is the starting point that is misleading. First, the Western European governments considered the CSCE to be a useful tool of their détente policy, whereas the United States did not. Secondly, Western European governments looked at détente as an opportunity to change the political scenario in Europe. They aimed at promoting a gradual loosening of bipolar restraints and at deepening the two blocs' mutual interdependence. To this aim, they proposed to expand economic and cultural contacts and exchanges and start a mutually advantageous cooperation in several fields. In the short and mid term, détente had to improve the daily life of European citizens and promote wider human contacts and mutual knowledge, whatever the regimes and the military alliances. In the long run, this effective dialogue was to overcome Moscow's mistrust towards more open contacts and reforms and therefore help a certain degree of liberalization of Communist regimes. Western European governments' détente was a dynamic and revolutionary process to be set in European relations with the purpose to overcome the Cold War confrontation and opposition in the 
continent and to the primary benefit of the European citizens. ${ }^{49}$ It could therefore be hardly compatible with the global strategy of the superpowers, whose dialogue aimed at avoiding confrontation, but also strengthened their interest in the perpetuation of the bipolar order in order to handle major international problems and crises. ${ }^{50}$

In the first major foreign policy pronouncement of the Ford administration, Secretary Kissinger speaking to the Senate Foreign Relations Committee on September 19, 1974, strongly invited Congress to approve the U.S.-Soviet trade accords of 1972 and not to tie such agreements to internal Soviet political developments such as human rights abuses. He linked bilateral détente to "responsible international behaviour by the Soviet Union," which he said it would be used as "the primary index of our relationship." ${ }^{11}$ From Kissinger's point of view "the temptation to combine détente with increasing pressure on the Soviet Union . . . would be disastrous. We would not accept it from Moscow; Moscow will not accept it from us. We will finally wind up again with the cold war and fail to achieve either peace or any human goal." ${ }^{, 52}$ The insistence on applying linkage between international agreements and internal Soviet political liberalization seriously reduced both Soviet convenience of further developing détente and American leverage in détente diplomacy.

\section{From Carrot to Stick: The Last Months of the CSCE}

In 1975, the Ford administration changed its views and attitude, and became more helpful to the Western cause at the CSCE. First, Kissinger's statements on the conference were inconsistent with the presidential statements favoring a top-level final stage. It was therefore the case for him to align to the official position of the president, all the more so given the growing coalition in Congress and the public opinion against détente. Second, the European allies had shown no intention in hastening the negotiations or giving up their requests, and the Atlantic solidarity would be better served by a more cooperative American posture. Last, but most important, a reappraisal of the relationship with Moscow induced a change in the U.S. foreign policy and inevitably produced its effects on the CSCE.

FCO 28/1692, A Federal Trust Report, "The European Community and the Conference on Security and Cooperation in Europe," July 16, 1972, NA; Minute from Mr. Tickell to Mr Wiggin, FCO, March 6, 1972, confidential. Document no. 2, in Documents on British Policy Overseas.

The amount of sources on this topic is overwhelming. See, for example, Memorandum for Kissinger from Sonnenfeldt, "MBFR-CSCE," August 21, 1972, NSC HAK Office Files, Box 67, Folder 5, NPM.; Tel. no. 30644 from AmEmbassy Paris to SecState Washington, "The French view of US-Soviet Détente," 29 November 29, 1973, NSC Country Files, Box 679,

Folder 2 (1 of 2), NPM. As for the literature, see for example, Rosenthal, "America's Move,"; Raymond L. Garthoff, Détente and Confrontation; Robert S. Litwak, Détente and the Nixon Doctrine: American Foreign Policy and the Pursuit of Stability, 1969-76 (New York, 1984). 
In early 1975, the economic crisis that had hit the industrialized countries after the oil shock in 1973 markedly invested the United States: unemployment, inflation, a growing balance deficit, and the deepest recession since the thirties. In his first speech on the state of the Nation, President Gerald Ford affirmed, "The state of the Union is not good." He therefore declared that the first goal of the administration was to recover the American economy and thus postponed the building of good international relations. The order of U.S. priorities was clear: "A resurgent America would do more to restore the confidence of the world in its own future than anything else we can do." ${ }^{53}$ As soon as the United States questioned their ability to flourish unendingly, another blow hit the American self-confidence. In early 1975, the situation in Vietnam collapsed, with North-Vietnamese Communist troops flooding into the South. On April 21, the Communists entered Saigon. President Van Thieu dismissed and the American evacuation looked seriously like an immediate escape.

The United States thus perceived itself in economic, political, and above all moral decadence. It was necessary to rethink the American international role and the relationship with the Soviet Union in particular. Kissinger, who had personally negotiated the American withdrawal from Vietnam, was confronted with the caducity of the Paris Agreement. Although he declared himself willing to continue the détente policy, he also stated that détente could not be selective, it had its own rules and, consequently, the pursuit of gains at the expenses of the counterpart would engender due consequences: "We shall never forget who supplied the arms which North Vietnam used to make a mockery of its signature on the Paris accords." 54

The White House had also to consider the changed sensibility of the country and its representatives. The Watergate scandal had revealed the dangerousness and the degeneration of "imperial" presidency and secretive elaboration of policies. Congress had consequently showed its determination to reassume its constitutional role and to restore the institutional balance. More specifically, the attention of Congress and public opinion had progressively focused on human rights issues. A clear signal came from the Jackson-Vanik amendment to the Trade Act. It conditioned the concession of the mostfavored nation clause with the Soviet Union to the facilitation of Jewish migration from that country. Despite the White House's attempts to mediate with senators, Congress passed the amended Trade Act on January 3, 1975. One

\footnotetext{
53

White House Press Release Unit, Presidential Statements, 1974-1977, "President's State of the Union speech," January 1974, FPL. 
week later, the Soviet Union denounced the trade agreement on the basis of violation of the noninterference clause of the U.S.-Soviet declaration on mutual relations. By linking the respect for human rights to trade issues, Congress had clearly claimed that U.S. détente policy did not ignore the fundamental values and the historical mission of the United States. ${ }^{55}$ Although Senator Jackson's action was mostly based on machinations relating to his political career, ${ }^{56}$ it combined with the conjunction of perceived interests of liberal pro-Jewish and pro-human rights groups, on the one hand, and conservative anti-Soviet, anti-détente constituencies, on the other, and played a critical role in mining the détente policy of the administration.

President Ford and Secretary of State Kissinger had to draw the consequences out of Congress's change of attitude and modified the American posture on foreign policy and the CSCE. Kissinger's words are particularly meaningful in this sense. He informed the publishers of the main American newspapers of his updated view: "We must give up the illusion that foreign policy can choose between morality and pragmatism. America cannot be true to itself unless it upholds human values and the dignity of the individual ... The American people must never forget that our strength gives force to our principles and our principles give purpose to our strength." 57 The president himself determined to face the growing public protest by bringing the administration position close to the feelings of the population. He in fact declared, "Peace is crucial, but freedom must come first ... The American people are still dedicated to the universal advancement of individual rights and human freedom." ${ }^{58}$

Kissinger stated that the final stage of the CSCE did not depend on American decision, but rather on the results of the Geneva negotiations, where important questions still lay unsolved: the Confidence-building Measures (CBMs), human contacts, CSCE follow-up. He added that the best way to hasten the conclusion of the conference was for the Soviets to give serious consideration to the Western proposals on those issues. ${ }^{59}$ The tone of U.S.-Soviet bilateral talks changed as well. When the Soviets complained about the rigidity of the U.S. delegation to the CSCE, Kissinger

\footnotetext{
55

Presidential Country Files for Europe and Canada, Box 1, Folder: Europe-General

(1), Memorandum for Scowcroft from Springsteen, "Issues Paper on US-Eastern European Relations," January 23, 1975, FPL.

See, on this theme, P. Stern, Water's Edge: Domestic Politics and the Making of American

Foreign Policy (Westport, CT, 1979); and W. Korey, "The Story of the Jackson Amendment, 1973-1975," Midstream 21 (March 1975): 7-36.

Maresca, To Helsinki,: 121. See also H.A. Kissinger, "The Moral Foundations of Foreign Policy," Atlantic Community Quarterly. 13, no. 3 (Fall 1975); 270-281. 
overturned the charge against the Soviets. ${ }^{60}$ The NATO meeting on May 29 and 30 sanctioned the American redefinition of détente policy and brought it back in harmony with the European allies. The U.S. delegation actively helped maintaining the unity and firmness of the Western camp that made it possible to achieve satisfactory results in the Final Act. President Ford declared the U.S. willingness to cooperate on the development of a realistic and effective détente that might serve Western interests and values. He added that one of the West's goals was to assure that CSCE promises be turned into practical actions for the progress of freedoms and dignity of all European citizens. These principles and aims were reaffirmed in Ford's statement at Helsinki, when signing of the Final Act. ${ }^{61}$ In conclusion, it is not possible to overlook the influence of domestic factors on the reappraisal of the U.S. détente policy and, consequently, on the U.S. attitude at the CSCE. However, it is also evident that misunderstanding the interpretation of détente rules on the part of the superpowers played a substantial role. Ford and Kissinger interpreted the Vietnam unification under the Communist regime as an indirect lack of compliance of the Kremlin to the basic code of conduct in U.S.-Soviet relations. Accordingly, they were no more inclined to use the CSCE as a good carrot, all the more so given the bad consequences that the U.S. attitude had had over the Atlantic cohesion and confidence. The realignment of the United States to the Western European governments' tough posture at the CSCE was certainly perceived by the Soviet counterpart as a stick.

\section{c on c l us i on}

In Nixon's conception, a new and more cooperative relationship between the superpowers was the key to stabilizing the international order and to gaining the United States more freedom of action in managing the important challenges of the seventies: Vietnam, economic problems, military budget cuts, public opinion's fears of a nuclear clash. It was, then, necessary, to recognize the Soviet Union as a basic pillar of the international order and to keep alive Moscow's interest in such a role via incentives. On the other hand, the United States would punish Soviet actions aimed at profiting from crises in order to advance its position vis-à-vis Washington. It was the linkage theory, or the technique of the carrot and stick. In order to involve the Soviet Union in this kind of relationship, Nixon toned down the ideological aspect in the American policy and chose a very pragmatic attitude.

The development of détente opened the way to the acceptance of the Soviet proposal for a pan-European conference by the Western governments. The NATO Communiqué of December 1969 considered such a conference a feasible option in the East-West dialogue. 
The CSCE entered in the complex "Nixongerian" strategy of involving the USSR in the management of the bipolar order. It was not a proper element of the U.S. détente policy. The Nixon administration had little interest in the CSCE. Neither Nixon nor Kissinger expected any practical results from it. They thought it would provide at least "atmospheric détente." Mostly the United States decided to accept the CSCE to avoid upsetting Western European allies that were more interested in the event. However, the CSCE provided the Nixon administration with a good "carrot" to induce the Soviets to be more cooperative on other issues. In fact, from 1969 to 1972, the White House used the Soviet desire of convening the CSCE as a bargaining chip in order to obtain concessions on such fundamental issues as the Quadripartite Agreement on Berlin, the first SALT agreement, and the Soviet consent to start negotiations on the MBFR.

Once the United States obtained satisfaction on these requests, the CSCE was deprived of its bargaining value and became the promised concession to the Soviets, who had major interests in pursuing it. The Nixon-Brezhnev Summit in Moscow, in May 1972, and particularly the Declaration on Principles guiding the U.S.-Soviet relations endorsing the Soviet concept of peaceful coexistence, seemed to turn détente between the superpowers into a sort of entente. The good relationship with Moscow was crucial for the most important goal of the Nixon administration in a year of elections: the honorable American withdrawal from Vietnam. The impression of a sort of superpowers' condominium was confirmed by the U.S. attitude at the CSCE a few months later. When the MPT started in Helsinki the U.S. delegation adopted a low profile, if not passive attitude. In June 1973, in a meeting with the NATO Permanent Representatives at San Clemente, Kissinger clearly stated that MBFR talks were much more important than the CSCE and that it was not helpful challenging the Soviets by asking for human contacts provisions or whatever else could be unacceptable to Moscow. From the Helsinki MPT to Nixon's resignation, the United States remained passive on human contacts or even pressed upon allies to speed up the negotiations and let a CSCE conclusive summit occur as soon as possible. Kissinger's numerous statements on the White House's indifference to the CSCE and on the pointlessness of the human contacts issue contributed to alienating the Europeans and feeding their suspicions of a possible entente over their heads. "A short snappy Conference with little substance" and a summit final stage for Brezhnev's personal success was the good carrot to buy the Soviet support on more substantial international questions (e.g., SALT II, Middle East, MBFR). Far from "honeymooning" with the Soviets, the White House was simply applying diplomatic means likely to preserve and further develop its strategy of dialogue with the USSR. The attempts to link international agreements to Soviet political liberalization would seriously reduce both Soviet interests in further developing détente and American leverage in détente diplomacy. For the 
White House, the primary index of the U.S. relationship with the Soviet Union was the latter's responsible behavior in international relations.

In fact, the cooperative relation between the United States and the Soviet

Union on the CSCE did change sensibly when the latter showed, according to American opinions, its aggressive face. When, in the spring of 1975, Vietnam was unified under the Communist regime, Kissinger bitterly affirmed, "We shall never forget who supplied the arms which North Vietnam used to make a mockery of its signature on the Paris accords." Washington realigned on the more intransigent Western Europeans' positions: the CSCE, and its Third Basket on human issues, became the stick to punish Soviet aggressive, or at least not sufficiently cooperative, policy in the rest of world (Asia, Africa). 